\title{
Identifikasi Alih Fungsi Lahan Pertanian dan Kondisi Sosial Ekonomi Masyarakat Desa Karangwidoro Kecamatan Dau Kabupaten Malang
}

\author{
Abd. Haris, Lutfi Bagus Subagio, Fajar Santoso dan Neni Wahyuningtyas \\ Masuk: 04052018 / Diterima: 28062018 / Dipublikasi: 31062018 \\ (c) 2018 Fakultas Hukum dan IImu Sosial UNDIKSHA dan IGI
}

\begin{abstract}
Land is a strategic resource that has value economically. Currently, the amount of agricultural land annually continues to decrease. The reduced number of agricultural land is the result of an increase in the number and activity of the population and development activities. The research method used in this research is qualitative. This study attempts to examine the conversion of agricultural land and its impact on the socio-economic conditions of the communities of Karangwidoro Village. Based on the results of the research note that land transfer function in Karangwidoro Village including the type of massive transfer of functions. Almost all kawsan Karangwidoro village is now a settlement, whereas previously a farming area. The area of land that has been transformed into housing from 2003 to 2017 is approximately 193 hectares. As a result of the conversion of agricultural land into housing makes the people of Karangwidoro Village experiencing the transition of livelihood or commonly referred to as economic transformation.
\end{abstract}

Keywords: Land Functionality Transfer; Agriculture; Social

\begin{abstract}
Abstrak Tanah merupakan sumberdaya strategis yang memiliki nilai secara ekonomis. Saat ini, jumlah luasan tanah pertanian tiap tahunnya terus mengalami pengurangan. Berkurangnya jumlah lahan pertanian ini merupakan akibat dari adanya peningkatan jumlah dan aktivitas penduduk serta aktivitas pembangunan. Metode penelitian yang digunakan dalam penelitian ini adalah kualitatif. Penelitian ini berupaya untuk mengkaji alih fungsi lahan pertanian dan dampaknya terhadap kondisi sosial ekonomi masayarakat Desa Karangwidoro. Berdasarkan hasil penelitian diketahui bahwa Alih fungsi lahan di Desa Karangwidoro termasuk jenis alih fungsi yang masif. Hampir seluruh kawsan Desa Karangwidoro saat ini menjadi pemukiman, padahal sebelumnya merupakan kawasan pertanian. Luas lahan yang berubah menjadi perumahan sejak 2003 hingga 2017 kurang lebih sekitar 193 hektar. Akibat alih fungsi lahan pertanian menjadi perumahan menjadikan masyarakat Desa Karangwidoro mengalami peralihan mata pencaharian atau biasa disebut dengan istilah transformasi ekonomi.
\end{abstract}

Kata kunci: Alih Fungsi Lahan; Pertanian; Sosial

\section{Pendahuluan}

Tanah merupakan sumberdaya strategis yang memiliki nilai secara ekonomis. Saat ini, jumlah luasan tanah pertanian tiap tahunnya terus mengalami pengurangan. Berkurangnya jumlah Iahan pertanian ini merupakan akibat dari adanya peningkatan jumlah dan aktivitas penduduk serta aktivitas pembangunan. Hal tersebut mengakibatkan permintaan akan lahan pun meningkat. Pada akhirnya, terjadilah konversi lahan

Abd. Haris, Lutfi Bagus, Fajar S, dan Neni Wahyuningtyas Fakultas IImu Sosial Universitas Negeri Malang bee amoy@yahoo.co.id, neni.wahyuningtyas.fis@um.ac.id pertanian ke non pertanian seperti perumahan, industri, dan lain sebagainya untuk memenuhi permintaan yang ada. Konversi lahan yang terjadi tidak lepas dari kepentingan berbagai pihak seperti pemerintah, swasta dan komunitas (masyarakat).

Salah satu desa yang mengalami perubahan sosial tersebut adalah Desa Karangwidoro Kecamatan Dau Kabupaten Malang. Desa tersebut merupakan desa yang mengalami perubahan sosial akibat alih fungsi lahan yang dilakukan oleh pihak perusahaan asing. Desa Karangwidoro mulanya merupakan desa pertanian. Luas tanah yang digunakan 
sebagai lahan pertanian lebih luas jika dibandingkan dengan luas tanah yang digunakan untuk rumah warga. Keasrian Desa Karangwidoro serta letaknya yang tidak terlalu jauh dari pusat Kota Malang menarik perhatian pengusaha asing untuk memanfaatkan lahan yang ada disana.

Sekitar tahun 1990an, pemilik tanah yang berada dipinggir jalan dan paling dekat dengan saluran irigasi membutuhkan uang untuk biaya pengobatan. Karena kebutuhan yang sangat mendesak, maka pemilik tanah tersebut akhirnya menjual tanahnya kepada pihak asing. Akibat yang ditimbulkan dari dijualnya tanah yang berada dipinggir jalan dan didekat saluran irigasi membuat tanah yang berada jauh lebih dalam tidak bisa dimasuki dan tidak mendapat air dari irigasi. Dampak yang muncul dari kasus ini adalah seluruh pemilik tanah dikawasan tersebut akhirnya menjual tanahnya kepada pihak asing. Setelah tanah terbeli oleh pengusaha asing, mereka mulai mengganti fungsi lahan yang ada di Desa Karangwidoro. Tanah pertanian yang semula merupakan lahan produktif berubah menjadi perumahan. Banyak warga yang bekerja dibidang pertanian kehilangan pekerjaan mereka. Hal ini senada dengan pendapat Suratha (2015) bahwa meluasnya konversi lahan menjadi penyebab utama para petani meninggalkan sawahnya.

Sebelum adanya alih fungsi lahan, mayoritas penduduk hanya menggantungkan kegiatan ekonominya pada pertanian saja. Namun setelah adanya alih fungsi lahan hampir tidak ada yang menggantungkan kegiatan ekonominya pada pertanian. Kebanyakan beralih menjadi kuli bangunan, pedagang, pelayan toko, tukang taman dll.

\section{Metode}

Pendekatan penelitian yang digunakan dalam penelitian ini adalah penelitian yang menggunakan pendekatan kualitatif. Menurut Sugiyono (2009) mengemukakan bahwa penelitian kualitatif memandang objek sebagai sesuatu yang dinamis, hasil konstruksi pemikiran, dan interpretasi terhadap gejala yang diamati serta utuh (holistik). Hal ini dikarenakan setiap aspek dari objek itu mempunyai satu kesatuan yang tidak dapat dipisahkan, jadi realitas itu merupakan konstruksi atau interpretasi dari pemahaman terhadap semua data yang tampak di lapangan.

Penelitian ini berupaya untuk mengkaji alih fungsi lahan pertanian dan dampaknya terhadap kondisi sosial ekonomi masayarakat Desa Karangwidoro. Adapun lokasi penelitian ini yaitu Desa Karangwidoro Kecamatan Dau Kabupaten Malang. Peneliti melakukan proses analisis data dimulai dengan menelaah seluruh data yang tersedia dari berbagai informan, yaitu dari hasil observasi, wawancara, dan dokumentasi. Dalam proses analisis data, peneliti juga mengatur secara sistematis data yang diperoleh sehingga lebih mudah dalam proses penyajiannya.Proses analisis data ini dilakukan secara interaktif dan berlangsung secara terus menerus sampai tuntas, sehingga datanya jenuh dan data yang diperlukan dapat terpenuhi (Miles \& Huberman, 1992).

\section{Hasil dan Pembahasan}

\section{Alih Fungsi Lahan Pertanian Desa Karangwidoro Kecamatan Dau Kabupaten Malang}

Lahan pertanian yang berada di Desa Karangwidoro adalah lahan jenis sawah. Lahan di Desa Karangwidoro memiliki saluran irigasi yang dibangun dari sungai yang melewati desa tersebut. Selain itu, Desa Karangwidoro terletak di wilayah yang tidak terlalu jauh dari pusat Kota. Hal inilah yang membuat Desa Karangwidoro memiliki daya tarik untuk para pengembang membangun perumahan di desa ini. Suasana yang masih asri sesuai pedesaan dan didukung letaknya yang tidak terlalu jauh dianggap oleh pengembang memiliki nilai jual yang tinggi jika dibangun perumahan. Fakta ini 
didukung oleh teori yang dikemukakan oleh Lestari (2012) yang mengungkapkan bahwa konversi lahan pada lahan sawah lebih besar jika dibandingkan dengan konversi lahan di tanah kering. Hal ini dipengaruhi oleh tiga faktor yaitu: (1). Pembangunan kegiatan non-pertanian seperti perumahan, pertokoan, kompleks perumahan dll lebih mudah dilakukan di sawah yang datar; (2). Infrastruktur ekonomi lebih tersedia di kawasan persawahan daripada dilahan kering; (3). Daerah persawahan umumnya terletak lebih dekat dengan konsumen yang berada di perkotaan jika dibandingkan dengan daerah lahan kering.

Teori tersebut juga seseuai dengan teori lqbal dan Sumaryanto (2007) yang menyatakan bahwa secara empiris, daerah pesawahan secara umum letaknya berada di dekat daerah perkotaan. Infrastruktur wilayah pesawahan memiliki kualitas yang lebih baik jika dibandingkan dengan wilayah lahan kering, hal tersebut yang menjadikan pembangunan prasarana dan sarana pemukiman, kawasan industri, dan sebagainya cenderung berlangsung cepat di wilayah pesawahan, dimana secara umum wilayah pesawahan yang berada di Pulau Jawa memiliki topografi datar sehingga lebih mudah untuk dibangun perumahan maupun kegiatan lainnya. Alih fungsi lahan di Desa Karangwidoro termasuk jenis alih fungsi yang masif. Hal ini dapat dilihat pada gambar berikut:

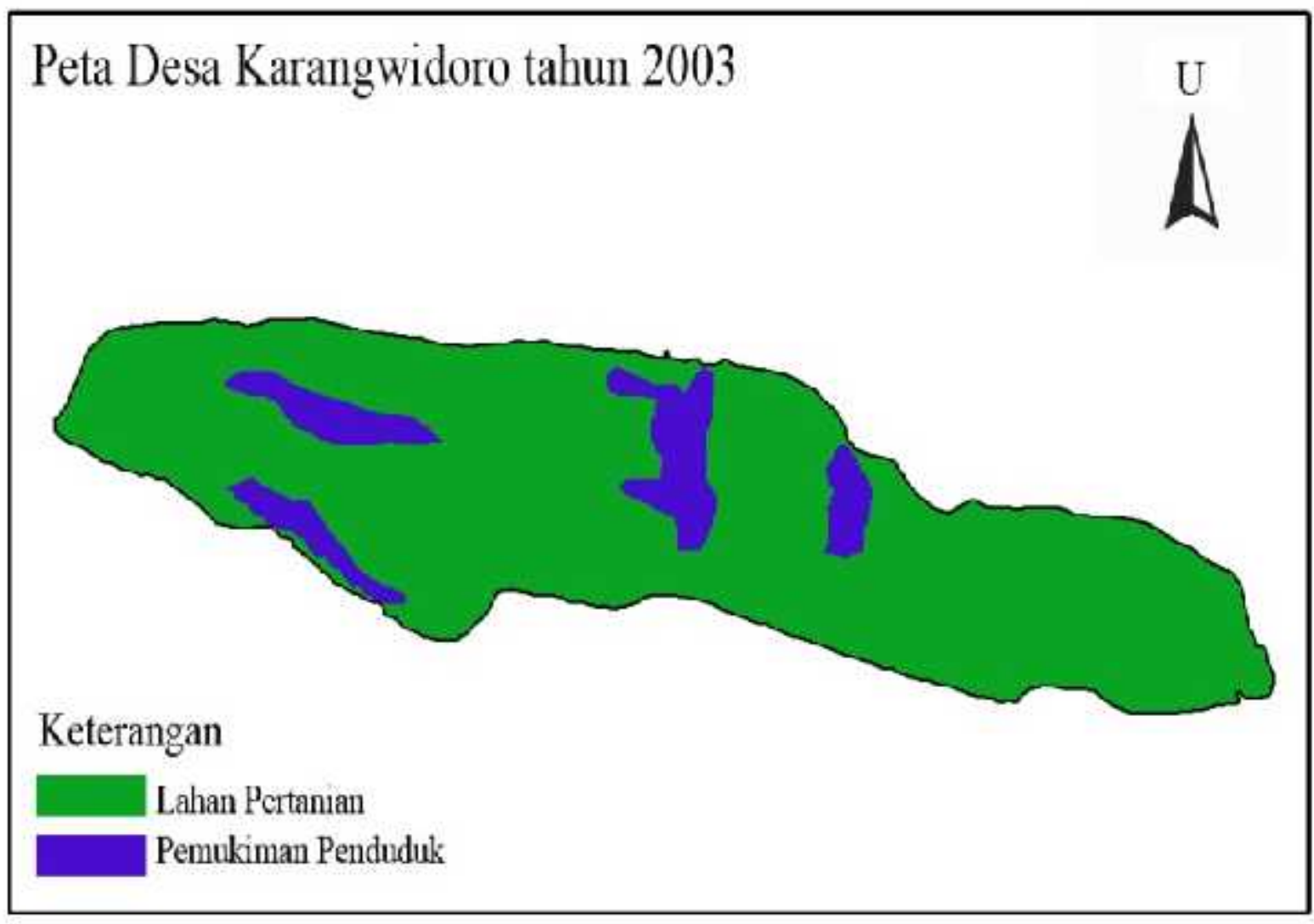

Gambar 1. Peta Desa Karangwidoro tahun 2003 


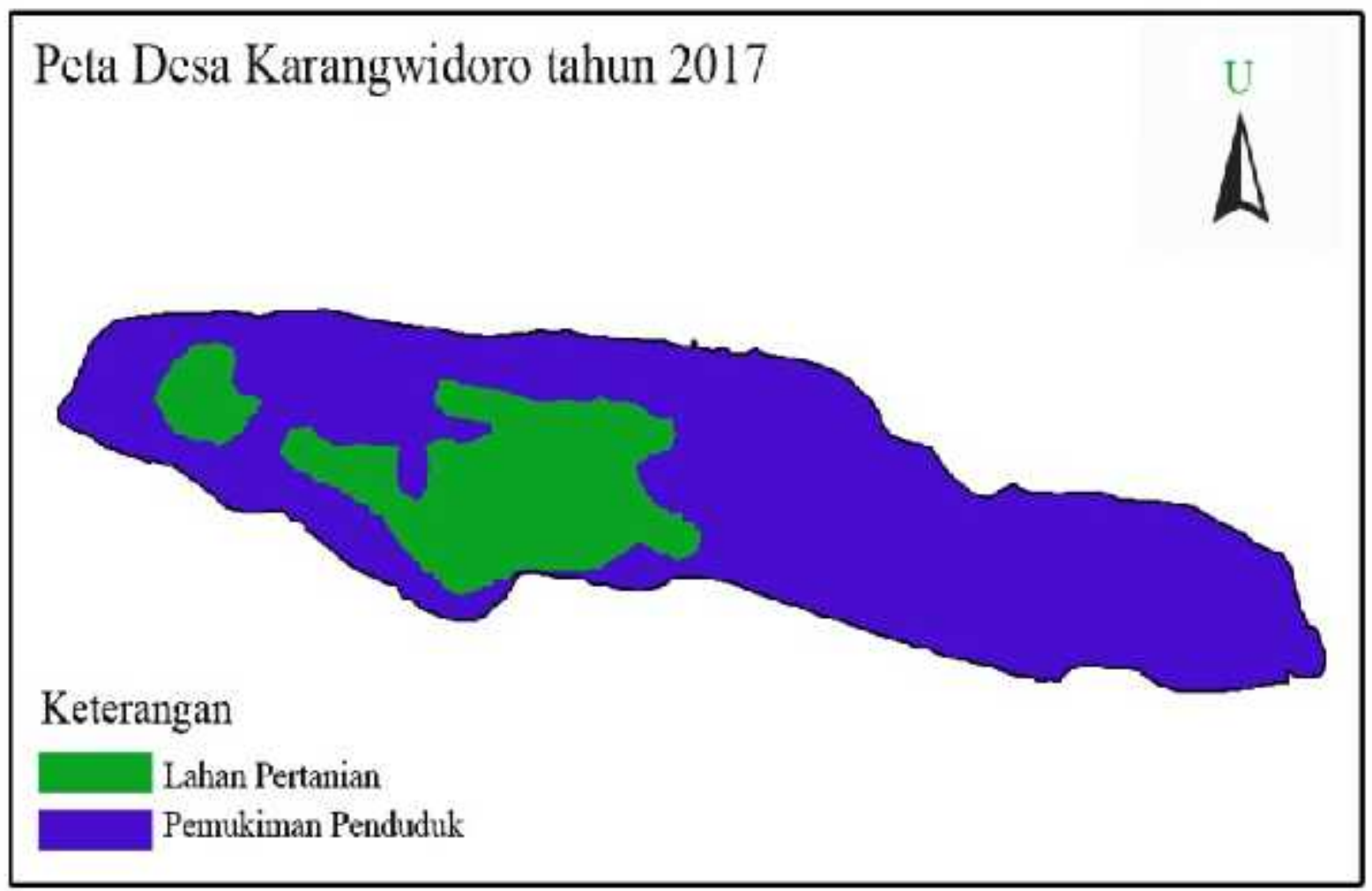

Gambar 2. Peta Desa Karangwidoro tahun 2017

Melalui kedua gambar diatas dapat diketahui bahwa berubahnya lahan pertanian yang menjadi pemukiman sangatlah drastis. Hampir seluruh kawsan Desa Karangwidoro saat ini menjadi pemukiman, padahal sebelumnya merupakan kawasan pertanian. Luas lahan yang berubah menjadi perumahan sejak 2003 hingga 2017 kurang lebih sekitar 193 hektar.

Alih fungsi lahan pertanian ke perumahan menyebabkan berubahnya lingkungan sekitar di Desa Karangwidoro. Sebelumya luas lahan pertanian di Desa Karangwidoro lebih luas daripada luas pemukimannya, namun saat ini justru pemukiman menjadi lebih luas dan lahan pertanian semakin menyempit. Menurut Widjanarko (2006) alih fungsi lahan yang terjadi menimbulkan dampak langsung maupun dampak tidak langsung. Dampak langsung yang diakibatkan oleh alih fungsi lahan berupa hilangnya lahan pertanian subur, hilangnya investasi dalam infrastruktur irigasi, kerusakan natural lanskap, dan masalah lingkungan. Kemudian dampak tidak langsung yang ditimbulkan berupa infasi penduduk dari wilayah perkotaan ke wilayah tepi kota.

Teori tersebut sesuai dengan temuan di Desa Karangwidoro, pasca alih fungsi lahan pertanian ke perumahan luas lahan terbuka hijau di Desa Karangwidoro menjadi berkurang. Berkurangnya lahan pertanian yang merupakan lahan terbuka hijau menjadikan harga beberapa bahan pangan di Desa Karangwidoro menjadi meningkat. Sebelumnya beberapa bahan pangan seperti bumbu dapur, sayuran sejenis dsb memiliki harga yang murah dan bahkan bisa didapatkan dengan gratis saat ini menjadi mahal karena harus membeli ke tukang sayur, tidak membeli langsung ke petani. Selain itu, berkurangnya ruang terbuka hijau memberikan dampak lain untuk masyarakat. Salah satunya adalah para peternak menjadi lebih sulit dalam mencari makan untuk hewan ternak mereka. Berkurangnya lahan terbuka hijau juga menyebabkan masalah lingkungan di Desa Karangwidoro. Seperti dikutip oleh liputan6.com (2002) Karangwidoro mengalami banjir lumpur pada bulan 
desember tahun 2012 dimana dalam tragedi tersebut mengakibatkan 1 orang meninggal dunia dan puluhan rumah menjadi hancur. Dampak lain yang ditimbulkan adalah dampak tidak langsung berupa semakin banyaknya infasi warga luar desa yang tinggal di desa ini. Warga tersebut menempati rumah di perumahan. Saat ini di Desa Karangwidoro banyak warga luar, meskipun demikian tidak pernah ada konflik antara warga desa dengan warga perumahan.

\section{Dampak Sosial Ekonomi Pasca Alih Fungsi Lahan}

Furi (2007) menjelaskan bahwa Perubahan dalam penguasaan lahan di pedesaan membawa implikasi bagi perubahan pendapatan dan kesempatan kerja masyarakat yang menjadi indikator kesejahteraan masyarakat desa.
Terbatasnya akses untuk menguasai lahan menyebabkan terbatas pula akses masyarakat atas manfaat lahan yang menjadi modal utama mata pencaharian sehingga terjadi pergeseran kesempatan kerja ke sektor non-pertanian. Masyarakat Desa Karangwidoro pun juga demikian. Pasca adanya alih fungsi lahan kesempatan kerja yang ada di Desa Karangwidoro menjadi bervariasi. Saat masih memiliki lahan, kesempatan kerja hanya ada petani dan buruh tani, beberapa ada yang memelihara hewan ternak. Namun ketika telah berdiri perumahan kesempatan kerja menjadi lebih luas. Hingga saat ini mata pencaharian masyarakat Desa Karangwidoro menjadi bervariatif. Berikut ini adalahh tabel mata pencaharian masyarakat di Desa Karangwidoro:

Tabel 2. Mata Pencaharian Penduduk Desa Karangwidoro tahun 2015

\begin{tabular}{cll}
\hline No & \multicolumn{1}{c}{ Mata Pencaharian } & \multicolumn{1}{c}{ Jumlah } \\
\hline 1. & Petani & 258 \\
2. & Pemborong/pengusaha & 186 \\
3. & Pedagang & 694 \\
4. & Pembantu rumah tangga & 428 \\
5. & Bangunan & 928 \\
6. & Angkutan & 98 \\
8. & Jasa lainnya & 769 \\
\hline
\end{tabular}

Sumber: Profil Desa Karangwidoro

Melalui tabel tersebut dapat diketahui bahwa alih fungsi lahan menjadi perumahan menjadikan masyarakat Desa Karangwidoro mengalami peralihan mata pencaharian atau biasa disebut dengan istilah transformasi ekonomi. Dewi \& Rudiarto (2013) menyatakan bahwa ketika ada terjadi transformasi ekonomi terjadi perbedaan antara petani yang memiliki modal lebih dan tidak. Petani yang memiliki modal lebih akan membuka usaha baru, namun untuk petani yang tidak memiliki modal lebih akan beralih menjadi buruh. Begitupun dengan masyarakat Desa Karangwidoro, petani yang memiliki modal lebih dalam hal ini adalah pemilik tanah menggunakan uang dari hasil penjualan tanah mereka untuk membeli tanah baru di daerah lain yang harganya lebih murah, sebagaian lagi masyarakat menggunakan uangnya untuk membuka usaha seperti membuka warung atau toko dan sebagaian lagi membeli bedak (kios) di pasar untuk berjualan sayur. Berbeda dengan petani pemilik tanah, para buruh tani yang bisa dikatakan tidak memiliki modal lebih mereka beralih pekerjaan dengan memanfaatkan pembangunan perumahan. Kebanyakan menjadi kuli atau tukang bangunan, sedangkan lainnya bekerja di sektor jasa seperti pembantu rumah tangga, satpam, tukang cukur dll.

Berdasarkan hasil wawancara, kehidupan masyarakat saat ini lebih baik jika dibandingkan ketika masih menjadi 
buruh tani. Mereka mengaku ketika menjadi buruh tani hasil yang didapat hanya cukup untuk makan sehari-hari. Namun untuk saat ini mereka mampu menyisihkan uang untuk membeli barang berharga bahkan membangun rumah. Mereka juga mengaku memiliki uang yang cukup untuk biaya sekolah anak-anak mereka. Masyarakat mengaku ketika menjadi buruh tani pekerjaan sampingan yang mungkin dilakukan hanya memelihara tukang ternak, namun untuk saat ini lebih banyak peluang untuk melakukan pekerjaan sampingan sebagai salah satu cara untuk menambah penghasilan.

Peristiwa transformasi ekonomi masyarakat Desa Karangwidoro jika digambarkan dengan bagan akan tampak sebagai berikut:

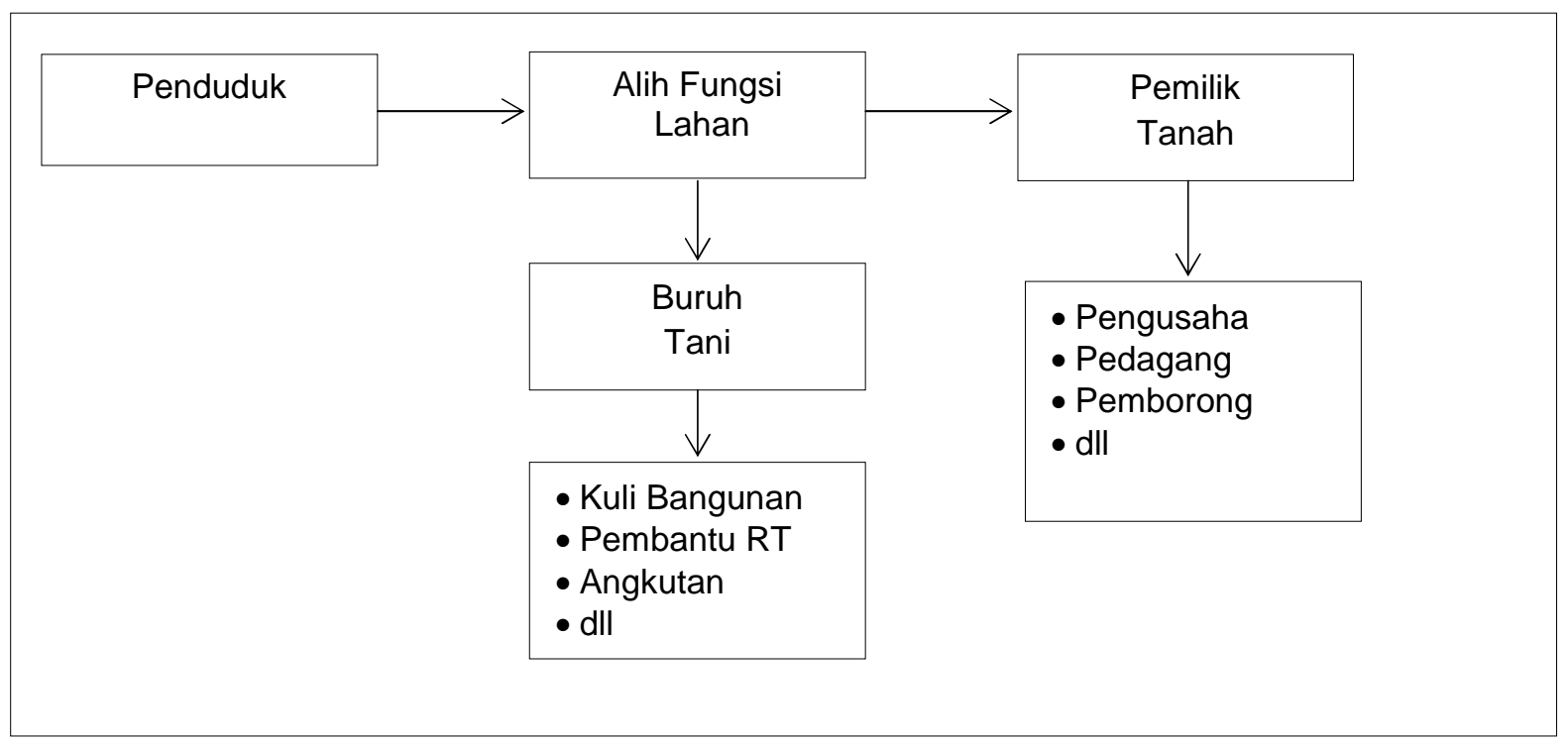

Gambar 3. Skema Transformasi Ekonomi Masyarakat Desa Karangwidoro

Menurut Yunus (2008) perubahan yang terjadi seperti hal diatas akan membawa dampak memudarnya kekerabatan antar warga. Berkurangnya kekerabatan akan mengubah masyarakat yang kental akan kekerabatan atau biasa disebut paguyuban (gameinschaft) menjadi masyarakat yang individualistik (gesselschaft). Teori tersebut tidak berlaku untuk masyarakat Desa Karangwidoro. Masyarakat Desa Karangwidoro tetap menjaga kekerabatan antar warga, bahkan perkumpulan masyarakat di desa ini semakin berkembang. Selain itu, masyarakat Desa Karangwidoro tetap menjaga identitas sebagai suku Jawa. Dalam hal kegiatan sosial, masih tercium akulturasi budaya Islam dan Jawa. Hal tersebut dapat dibuktikan dengan adanya budaya nyadran, selametan, mithoni dsb serta masih digunakannya hitungan kalendar Jawa ketika akan acara khitanan maupun nikahan.

\section{Kesimpulan}

Alih fungsi lahan di Desa Karangwidoro termasuk jenis alih fungsi yang masif. Hampir seluruh kawsan Desa Karangwidoro saat ini menjadi pemukiman, padahal sebelumnya merupakan kawasan pertanian. Luas lahan yang berubah menjadi perumahan sejak 2003 hingga 2017 kurang lebih sekitar 193 hektar. Akibat alih fungsi lahan pertanian menjadi perumahan menjadikan masyarakat Desa Karangwidoro 
mengalami peralihan mata pencaharian atau biasa disebut dengan istilah transformasi ekonomi.

Petani di Desa Karangwidoro yang memiliki modal lebih, dalam hal ini adalah pemilik tanah menggunakan uang dari hasil penjualan tanah mereka untuk membeli tanah baru di daerah lain yang harganya lebih murah. Sebagaian lagi masyarakat menggunakan uangnya untuk membuka usaha seperti membuka warung atau toko dan sebagaian lagi membeli bedak (kios) di pasar untuk berjualan sayur. Berbeda dengan petani pemilik tanah, para buruh tani yang bisa dikatakan tidak memiliki modal lebih mereka beralih pekerjaan dengan memanfaatkan pembangunan perumahan. Kebanyakan menjadi kuli atau tukang bangunan, sedangkan lainnya bekerja di sektor jasa seperti pembantu rumah tangga, satpam, tukang cukur dll.

\section{Daftar Pustaka}

Dewi, N. K., \& Rudiarto, I. (2013). Identifikasi Alih Fungsi Lahan Pertanian dan Kondisi Sosial Ekonomi Masyarakat Daerah Pinggiran di Kecamatan Gunungpati Kota Semarang. Jurnal Wilayah Dan Lingkungan, 1(2).

Furi. (2007). Implikasi Konversi Lahan Terhadap Aksesibilitas Lahan dan Kesejahteraan Masyarakat Desa. Institut Pertanian Bogor.

Lestari, T. (2012). Dampak Konversi Lahan bagi Kehidupan Petani. Bogor. Bogor: Kolokium Sains dan Pengembangan Masyarakat IPB.

Miles, M. B., \& Huberman, A. M. (1992). Qualitative Data Analysis: An Expanded Source Book. Thousand Oaks CA: Sage Publication Inc.

Sugiyono. (2009). Metode Penelitian Kuantitatif, Kualitatif, Dan R\&D. Bandung: Alfabeta.

Suratha, I. K. (2015). Krisis Petani Berdampak pada Ketahanan Pangan di Indonesia. Media Komunikasi Geografi, 16(1).
Widjanarko. (2006). Aspek Pertanahan Dalam Pengendalian Alih Fungsi Lahan Pertanian (Sawah). Jakarta: Pusat Penelitian dan Pengembangan BPN.

Yunus, H. S. (2008). Dinamika Wilayah Peri-Urban Determinan Masa Depan Kota. Yogyakarta: Pustaka Pelajar. 